\title{
Kajian Budaya Visual Pasren Dan Transformasi Simbol Kebahagiaan Dan Kemakmuran Pada Masyarakat Modern (Tinjauan Strukturalisme Levi Strauss)
}

\author{
Hesti Rahayu \\ Dosen Program Studi Desain Komunikasi Visual \\ Fakultas Seni Rupa Institut Seni Indonesia Yogyakarta \\ nadacintaku@gmail.com
}

\begin{abstract}
Pasren as a symbol of worship of Dewi Sri in Javanese society, is one of the cultural phenomena. Even though Pasren is no longer well known, even forgotten, but is it true that Pasren is truly extinct, or is it just a form transformation (transformation) both in terms of concept and physical form? This paper tries to answer these questions using Levi-Strauss structural analysis, through the concept of grammar transformation to describe deep structure. The results of the observation show the occurrence of grammar transformation of the concept of happiness and well-being from the existence of $K B$ television and monument in Bantul, Yogyakarta.
\end{abstract}

Keywords: visual-culture,symbol, pasren, structural analysis, grammar-transformation.

Relevance to Visual Communication Design Practice: The discussion of visual culture with Levi Strauss's structuralism approach can be an alternative point of view in the research of Visual Communication Design in Indonesia.

\section{PENDAHULUAN}

Masyarakat Jawa khususnya di Jawa Tengah dan Daerah Istimewa Yogyakarta pada umumnya merupakan masyarakat agraris. Mata pencaharian pokok adalah bertani. Tanaman pokok pada umumnya padi, karena masyarakat mempunyai kebiasaan makanan pokoknya nasi dari beras.

Dalam menanam padi, masyarakat sangat percaya bahwa keberhasilan tanamannya berkat restu dari sesuatu di luar kemampuan manusia, oleh karena itu orang harus selalu menghormatinya. Menurut kepercayaan, tanaman padi konon merupakan jelmaan dari Dewi Sri. Sehingga apabila orang ingin tanaman padinya subur dan menghasilkan yang baik, harus menghormati Dewi Sri.

Berbagai cara yang dilakukan yaitu dengan bersikap baik terhadap tanaman padi, dari waktu ke waktu membuat persemaian, menanam, mencabut rumput, mengusir hama, sampai proses pemanenan dan pasca panen. Di samping sikap baik dan berhati-hati terhadap tanaman padi, masyarakat membuat dan menyediakan tempat untuk menghormati Dewi Sri di tempat yang dipercayai sebagai tempat tinggalnya. Tempat ini disediakan di bagian rumah tinggal yang paling terhormat. Sebutan bagi tempat terhormat ini ada yang menyebut pedaringan, disebut pula pasren, ada pula yang menamakan krobongan.

Tentang wujud pasren sangat tergantung kepada kondisi dan status sosial pemiliknya. Ada yang sederhana dengan amben bambu, ada yang lebih baik, bahkan para keluarga raja membuat pasren sangat indah dan dengan kelengkapannya yang megah. 
Dalam kehidupan masyarakat saat ini, sebagian besar masyarakat Jawa dalam membangun rumah sudah mengalami perkembangan, sehingga pasren tidak lagi banyak dikenal, bahkan dilupakan. Akan tetapi apakah memang benar pasren telah benarbenar punah, ataukah hanya terjadi transformasi bentuk (alih-rupa) baik dari segi konsep maupun wujud fisiknya - sebagaimana dipaparkan Levi Strauss melalui konsep transformasi grammar - yang tetap meninggalkan struktur dalam (deep structure) sesuai dengan alam berpikir masyarakat pemiliknya tersebut? Tulisan ini mencoba untuk menjawab pertanyaan-pertanyaan tersebut dengan menggunakan analisis struktural Levi-Strauss.

\section{KONSEP TRANSFORMASI DAN STRUKTUR MENURUT LEVI STRAUSS}

Pasren sebagai suatu simbol pemujaan terhadap Dewi Sri dalam masyarakat Jawa, merupakan salah satu fenomena budaya. Fenomena budaya sendiri menurut Levi Strauss adalah gejala yang sifatnya diskontinyu. Menurutnya, bila kita mengamati berbagai fenomena budaya di dunia ini, maka akan terlihat seolah segala sesuatunya seolah kacau balau. Tetapi di balik kekacauan tersebut, sesungguhnya terdapat tatanan atau struktur tertentu (Strauss, 1997: 53). Itulah yang dimaksud dengan struktur oleh Levi-Strauss. Untuk menyingkap tatanan di balik fenomena budaya, Levi Strauss menggunakan pendekatan dengan model dari linguistik yaitu menempatkan fenomena budaya sebagai teks.

Menurut yang ditulis Ahimsa-Putra (Ahimsa-Putra: 2001, 66), ada beberapa asumsi dasar dalam pemikiran Levi Strauss yang harus kita ketahui untuk memahami strukturalisme
Levi Strauss, sekaligus dapat kita gunakan untuk memudahkan analisis terhadap fenomena budaya. Ada empat asumsi pokok yang terpenting di samping banyak asumsi dalam pemikiran ini:

Pertama, dalam strukturalisme ada anggapan bahwa berbagai aktivitas sosial dan hasilnya, seperti misalnya: dongeng, upacaraupacara, sistem-sistem kekerabatan dan perkawinan, pola tempat tinggal, pakaian dan sebagainya, secara formal semuanya dapat dikatakan sebagai bahasa-bahasa, atau lebih tepatnya merupakan perangkat tanda dan simbol yang menyampaikan pesan-pesan tertentu. Oleh karena itu terdapat ketertataan (order) serta keterulangan (regularities) pada berbagai fenomena tersebut.

Kedua, para penganut strukturalisme beranggapan bahwa dalam diri manusia terdapat kemampuan dasar yang diwariskan secara genetis, yaitu kemampuan untuk menstruktur (structuring), menyusun suatu struktur, atau 'menempelkan' suatu struktur tertentu pada gejala-gejala yang dihadapinya. Kemampuan dasar (inherent capacity) ini terdesain sedemikian rupa sehingga berbagai macam kemungkinan penstrukturan tersebut tidak lantas menjadi tanpa batas. Adanya kemampuan ini membuat manusia dapat (seolah-olah) 'melihat' struktur di balik berbagai macam gejala.

Struktur yang dimiliki gejala-gejala tersebut dibagi menjadi surface structure (struktur permukaan) dan deep structure (struktur dalam). Surface structure (struktur permukaan) terdapat pada struktur yang ada pada sebuah mitos, suatu sistem kekerabatan, sebuah kostum, sebuah rituil, tatacara memasak, tata penempatan ruangan, dan sebagainya. Deep structure (struktur dalam) 
merupakan struktur dari struktur permukaan, atau struktur dari struktur. Kalau struktur permukaan mungkin disadari adanya oleh para pelakunya, struktur dalam berada pada tataran yang tidak disadari adanya oleh para pelakunya, seperti yang ada pada bahasa. Orang bisa saja sadar akan struktur yang ada dalam bahasa yang mereka gunakan, namun hal semacam ini sangat jarang terjadi, dan seandainya pun dia menyadarinya, hal itu tidak membuat kesadaran ini bekerja ketika dia menggunakan bahasanya.

Dalam kehidupan sehari-hari apa yang kita dengar dan saksikan adalah perwujudan dari adanya struktur dalam tadi, akan tetapi perwujudan ini tidak pernah komplit. Suatu struktur hanya akan mewujud secara parsial pada suatu gejala seperti halnya suatu kalimat dalam bahasa Indonesia hanyalah wujud dari secuil struktur bahasa Indonesia. Jadi struktur ini bukanlah apa yang kita lihat dan dengar dalam kenyataan, akan tetapi struktur tersebut dapat kita ketahui, kita abstraksikan, dari berbagai gejala yang nyata. Tugas dari peneliti yang menggunakan perspektif struktural pada awalnya adalah mengungkapkan struktur permukaan terlebih dahulu. Apabila ini telah dilakukan, langkah selanjutnya adalah mengungkap struktur dalam, yang dianggap ada 'di balik' berbagai fenomena budaya yang diteliti.

Ketiga, mengikuti pandangan dari Saussure yang berpendapat bahwa suatu istilah ditentukan maknanya oleh relasi-relasinya pada suatu titik waktu tertentu, yaitu secara sinkronis, dengan istilah-istilah yang lain, para penganut strukturalisme berpendapat bahwa relasi-relasi suatu fenomena budaya dengan fenomena-fenomena yang lain pada titik waktu tertentu inilah yang menentukan makna fenomena tersebut. Jadi relasi sinkronisnyalah yang menentukan, bukan relasi diakronisnya. Dalam menelaah suatu fenomena atau suatu sistem, relasi sinkronis ditempatkan mendahului relasi diakronis. Artinya sebelum perkembangan suatu sistem atau fenomena tersebut secara diakronis diketahui, harus diketahui lebih dulu kondisi sinkronisnya atau relasi-relasinya dengan fenomena yang lain dalam suatu titik waktu tertentu. Oleh karena itu, dalam menjelaskan suatu gejala penganut strukturalisme tidak mengacu pada sebabsebab karena hubungan sebab-akibat merupakan relasi diakronis, tetapi mengacu pada hukum-hukum transformasi. Transformasi di sini hendaknya tidak diartikan sebagai perubahan yang berkonotasi historis, diakronis, tetapi sebagai alih-rupa.

Hukum transformasi adalah keterulanganketerulangan (regularities) yang tampak, melalui mana suatu konfigurasi struktural berganti menjadi konfigurasi struktural yang lain. Hal ini dapat dijelaskan sebagai berikut. Kalau kita membandingkan pola-pola relasi yang ada pada gejala-gejala yang terpisah dalam ruang dan waktu misalnya, kita akan menemukan persamaan-persamaan dan perbedaan-perbedaan pada konfigurasi strukturalnya. Umumnya kita lantas akan mengatakan bahwa konfigurasi struktural ini hadir karena bekerjanya faktor-faktor tertentu. Tidak demikian halnya dengan penjelasan struktural. Lewat strukturalisme, konfigurasi struktural tersebut akan ditanggapi sebagi alihrupa (transformasi) dari konfigurasi struktural yang lain. Hasil dari pengamatan yang dilakukan berkali-kali kemudian akan sampai pada kesimpulan bahwa suatu struktur tertentu selalu beralih rupa dengan cara tertentu. Di sini yang kita dapatkan bukanlah hukum-hukum 
sebab-akibat, tetapi hukum-hukum transformasi.

Keempat, relasi-relasi yang berada pada struktur dalam dapat diperas atau disederhanakan lagi menjadi oposisi berpasangan (binary opposition) yang paling tidak, punya dua pengertian. Pertama, oposisi biner yang bersifat eksklusif seperti misalnya: kategori menikah dan tidak menikah. Pengertian yang kedua adalah oposisi biner yang tidak eksklusif, yang kita temukan dalam berbagai macam kebudayaan, seperti misalnya oposisi-oposisi: air-api; gagak-elang; siangmalam; matahari-rembulan dan sebagainya. Logikanya oposisi-oposisi ini memang tidak eksklusif, namun dalam konteks-konteks yang khusus, mereka yang menggunakannya menganggapnya eksklusif, sebagaimana terlihat pada mitos-mitos yang dianalisis oleh Levi-Strauss.

Dari paparan mengenai model dan asumsi dasar inilah, metode analisis struktural berupaya mencari 'tata-bahasa' yang ada di balik berbagai jenis fenomena budaya yang diteliti. Adapun langkah analisis dalam tulisan ini : Pertama, memaparkan perihal pasren dan hubungannya dalam kehidupan masyarakat Jawa. Kedua, pergeseran budaya yang terjadi di masyarakat semisal terjadinya perubahan bentuk rumah tinggal, mulai tiadanya pasren dikarenakan beberapa sebab, dan sebagainya. Ketiga, mengkaitkan poin pertama dan kedua dalam relasi-relasi transformasional untuk memperoleh struktur dalamnya (deep structure-nya).

Dalam analisis ini, kita tidak dapat melepaskan dari konsep mengenai pola pikir tradisional yang sering diibaratkan bricoleur atau bricolage oleh Levi-Strauss, yang berbeda dengan pola pikir modern. Bricoleur adalah semacam orang yang ahli dalam segala pekerjaan yang akan menggunakan apapun yang ada untuk membantu pekerjaan yang diilhami oleh "adhoisme" dengan bagianbagian buatan yang bertujuan (Badcock, 2006 : 59). Ia adalah semacam tukang reparasi yang jika ingin membuat sesuatu dia melakukannya berdasarkan atas apa-apa yang telah dimilikinya lebih dulu. Penggunaan seperangkat alat dan bahan yang ada yang digunakannya untuk membuat suatu barang baru yang berbeda dengan yang sudah ada sebelumnya inilah yang dimaksud oleh LeviStrauss sebagi bricolage, dan ia menyatakan bahwa inilah aspek penting dari pemikiran primitif. Cara yang dipakai oleh seorang tukang memang berbeda dengan cara yang digunakan oleh seorang "ingenieur". Seorang insinyur jika ingin membuat sesuatu akan lebih dulu merencanakan apa yang akan dibuatnya, dan baru kemudian dia akan mencari alat dan bahan yang diperlukan untuk membuat sesuatu tersebut (Ahimsa-Putra, 1997: xxxix). Ilmu modern menggunakan konsep-konsep buatan yang bertujuan dan sistem-sistem yang menjelaskan, sedangkan pemikiran primitif menggunakan objek-objek yang ada sebelumnya untuk melayani tujuan-tujuan intelektual yang baru (Badcock, 2006: 59).

Kecenderungan bricolage dalam pemikiran primitif menurut Levi-Strauss adalah untuk mentransformasikan tujuan ke dalam alat dan demikian pula sebaliknya. Dengan demikian sangat mungkin ditemukan bentuk-bentuk perwujudan alih-rupa yang wujudnya terkesan modern padahal di baliknya dilandasi oleh pemikiran primitif. 


\section{ARTI KEBERADAAN PASREN}

Dalam buku yang diterbitkan Bagian Proyek Pembinaan Permuseuman DIY "Pasren dalam Kehidupan Masyarakat Tradisionial Jawa" disebutkan bahwa kata pasren berasal dari bahasa Jawa pa+sri+an yang mempunyai arti tempat menghormati Dewi Sri. Kata pasren terdiri dari kata Sri yang berarti Dewi Sri (Dewi Padi). Kata Sri mendapat awalan pa dan akhiran an. Dalam tata bahasa Jawa, kata benda yang mendapat imbuhan tersebut akan berubah arti menjadi kata keterangan tempat. Jadi kata pasren kurang lebih mengandung arti tempat pemujaan terhadap Dewi Padi, yaitu Dewi Sri. Menurut Prof. Dr. Soedarsono seorang pakar kebudayaan Jawa, pasren bukan sekedar tempat pemujaan, akan tetapi merupakan tempat dimana Dewi Sri itu tinggal dan dianggap bersemayam di ruang tengah (senthong tengah), tempat yang mereka sediakan. Maka ruang tengah inilah yang digunakan sebagai tempat untuk mengadakan upacara penghormatan terhadap Dewi Sri. Nama Dewi Sri sendiri sebagai dewi padi sangat dihormati oleh para petani. Berhasil tidaknya panen mereka sangat tergantung atas kemurahan Dewi Sri. Para petani percaya bahwa Dewi Sri dapat dipanggil untuk keperluan mereka. Untuk dapat memenuhi permintaan, mereka harus menyediakan tempat khusus untuk Dewi Sri. Tempat khusus inilah yang kemudian disebut pasren. Karena rasa hormatnya para petani kepada Dewi Sri, pasren ditata sedemikian rupa, bersih dan indah, sedemikian asrinya demi menghimbau Dewi Sri memberikan berkahnya. Karena itulah sementara orang berpendapat pasren berasal dari kata asri (indah), sehingga pa-asri-an berarti tempat yang indah.

\section{LETAK PASREN DI RUMAH TRADISIONAL JAWA}

\section{A. Susunan Rumah Tradisional Jawa}

Untuk dapat menggambarkan letak pasren pada rumah tradisional Jawa, alangkah baiknya diketahui macam-macam bentuk rumah tradisional Jawa.

1. Rumah bentuk joglo, biasanya berbentuk bujur sangkar dan ber-ruang empat. Bentuk rumah semacam ini biasanya hanya dimiliki oleh golongan ningrat. Susunan ruangan rumah berbentuk joglo dibagi menjadi tiga bagian, yaitu:

a. Ruangan pertama yang disebut pendopo, memiliki bagian-bagian sebagai berikut:

1) Kuncung, merupakan suatu bentuk bangunan yang terdapat pada bangunan rumah tradisional bentuk joglo. Bangunan ini terletak pada bagian depan yang berfungsi sebagai penghubung pintu masuk ruangan pendopo.

2) Pendopo, bangunan yang terletak pada bagian depan dalam rangkaian rumah Jawa. Pendopo biasanya merupakan bentuk bangunan yang keadaaannya terbuka dan di bagian sisinya tanpa diberi tutup sedikitpun. Hal ini dimaksudkan agar tempat ini dapat digunakan untuk berbagai kegiatan sosial, baik itu intern maupun ekstern. Intern yaitu untuk pertemuan trah (Jawa) keluarga dan membahas berbagai kepentingan keluarga, sedangkan ekstern untuk kepentingan masyarakat setempat. Pendopo 
juga digunakan sebagai tempat menyelenggarakan pertunjukan seperti wayang orang, langen wanara, langen driyan, pertunjukan ketoprak, atau pertunjukan lainnya. Sering pula digunakan untuk menyuguhkan pagelaran kesenian kepada tamutamu yang datang dari luar.

b. Ruangan tengah atau ruangan yang dipakai untuk mengadakan tontonan wayang kulit yang disebut paringgitan. Letak paringgitan dalam rangkaian rumah tradisional Jawa, terletak antara ruangan pendopo dan dalem, berperan sebagai penghubung. Bangunan ini satu rangkaian dengan bangunan induk rumah pokok yang disebut dalem, menempati ruangan pada bagian depan rumah pokok dengan bentuk rumah beratap setangkep, yaitu rumah dengan dua bagian atap (empyak). Biasanya luas ruang paringgitan merupakan sepertiga dari luas ruangan rumah induk. Posisi lantai dibuat lebih tinggi dibanding lantai halaman luar yang disebut dengan pelataran, yang kondisinya menempati lantai pertama dari suatu bentuk susunan rumah tradisional Jawa yang dipakai sebagai dasar untuk berdirinya suatu rumah. Pada pelataran ini terdapat ruangan yang menghubungkan rumah pendopo dengan rumah induk/ dalem yang disebut dengan ratawahana (hantika wahana).

c. Ruangan belakang yang disebut dalem sebagai ruang keluarga. Letaknya di tengah-tengah dari suatu bentuk bangunan rumah. Bentuk ruangan ini biasanya berukuran sepertiga dari luas bangunan rumah induk, posisinya di belakang paringgitan. Dalam ruangan ini terdapat tiga buah senthong (kamar) yaitu:

- Senthong kiwa

- Senthong tengah, tempat pasren berada. Posisi bangunan lantai lebih tinggi dari lantai bangunan lainnya. Hal ini menunjukkan bahwa bangunan ini memiliki keistimewaan tersendiri dari bentuk bangunan lainnya. Ruangan ini menggambarkan pusat yang dipakai sebagai sentrum berbagai bentuk kegiatan yang bersifat sakral. Di ruangan ini pasren terletak, yang menggambarkan sentral kehidupan berpikir orang Jawa.

- Senthong tengen

d. Selain ruangan-ruangan tersebut di atas, terdapat pula gandok, yaitu rumah tambahan yang terletak di sebelah kiri atau kanan dan menempel atau bergandengan dengan rumah belakang. Arah membujurnya gandok ialah melintang pada rumah belakang. Jika antara rumah belakang dan gandok diberi longkangan atau sela/ pemisah, maka kedua jenis rumah tersebut perlu diberi penghubung yang disebut durlup. Rumah tambahan ini dipergunakan untuk menyimpan perabot dapur atau menyimpan berbagai macam peralatan atau atribut pertanian. Bisa juga ruangan ini dipakai sebagai tempat ruang makan, bahkan ada yang dipakai sebagai ruangan dapur. 
Sebenarnya gandok adalah dapur, tetapi adanya perluasan maka dapur dipindah pada bagian belakang rumah belakang, sedang batas dapur tersebut diubah menjadi gandok. Bagi orang yang mampu, biasanya gandok dibangun lebih baik dari rumah belakang.

2. Rumah limasan, memiliki bentuk empat persegi panjang dengan dua buah atap (kejen atau cocor), serta dua atap lainnya (brunjung) yang bentuknya jajaran genjang sama kaki seperti tutup keong. Karena cenderung berubah, maka rumah limasan mengalami perombakan sisinya yang disebut empyak (emper) atau atap emper. Rumah limasan ini biasanya dimiliki oleh kelompok kelas menengah (middle class).

Rumah berbentuk kampung, rumah kampung ini dapat diketahui dari reliefrelief yang terdapat pada candi Borobudur, Prambanan, dan candi-candi di Jawa Timur. Pada dasarnya bentuk rumah kampung terdapat di daerah pedesaan dengan kondisi status ekonomi kurang mampu, yaitu kelas ekonomi bawah (under class). Bentuk denah rumah kampung umumnya berbentuk empat persegi panjang.

3. Rumah bentuk masjid dan tajug (tarub), rumah semacam ini memiliki denah bujur sangkar dan bentuk inilah yang masih mempertahankan bentuk denah aslinya sampai sekarang. Jika terdapat perubahan itu hanyalah berdasarkan ukuran besar kecilnya luas bangunan, namun variasi itu tidak akan mengubah denah bujur sangkarnya.
4. Rumah bentuk panggang-pe, rumah bentuk ini biasanya merupakan bentuk rumah yang sederhana, lebih sederhana bila dibanding rumah kampung. Rumah berbentuk ini bukan jenis bentuk rumah hunian. Biasanya digunakan untuk peyimpanan atau penjemuran hasil-hasil ladang perkebunan. Misalnya untuk jemuran teh yang baru dipetik dari ladangnya, ketela pohon dan pengolahan padi. Biasanya banyak terdapat pada bangunan tempat berjualan di pasarpasar. Dalam bentuk besar didapat pada gedung-gedung pergudangan yang terdapat di pelabuhan-pelabuhan.

\section{B. Letak Pasren}

Masih menurut buku yang diterbitkan Bagian Proyek Pembinaan Permuseuman DIY "Pasren dalam Kehidupan Masyarakat Tradisionial Jawa”, disebutkan bahwa letak pasren dalam susunan rumah tradisional Jawa tidak lepas dari pengaruh agama Hindu yang memegang peranan penting dalam peradaban dan kehidupan masyarakat pada waktu itu, khususnya masyarakat Jawa.

Candi-candi Hindu di Jawa, pada umumnya dahulu dibangun sebagai tempat upacara keagamaan. Bagian-bagian candi biasanya menunjukkan tingkat kesucian tempat, yaitu dari bagian luar candi semakin masuk ke bagian dalam menunjukkan tempat yang lebih suci. Candi Prambanan misalnya, halaman terakhir dianggap yang paling suci yang disebut halaman pusat, dimana berdiri candi induk dengan komposisi Candi Siwa di bagian tengah, diapit oleh Candi Brahma di bagian selatan dan Candi Wisnu di bagian utara. 
Halaman paling suci dibatasi dengan pagar. Di bagian luarnya disebut halaman depan kedua, disitu berdiri candi-candi Perwara. Pada batas pagar berikutnya, di luar terdapat halaman lagi, yakni halaman ketiga sebuah halaman lingkungan candi. Bila diamati, letak pasren ternyata mengikuti pola seperti letak Candi Siwa yang merupakan bagian tersuci dalam susunan candi, yaitu berada di tengah (diapit senthong tengen dan senthong kiwa), ditempatkan dalam ruangan yang paling dalam yang dianggap paling suci, dan dibuat dalam model struktur punden berundak.

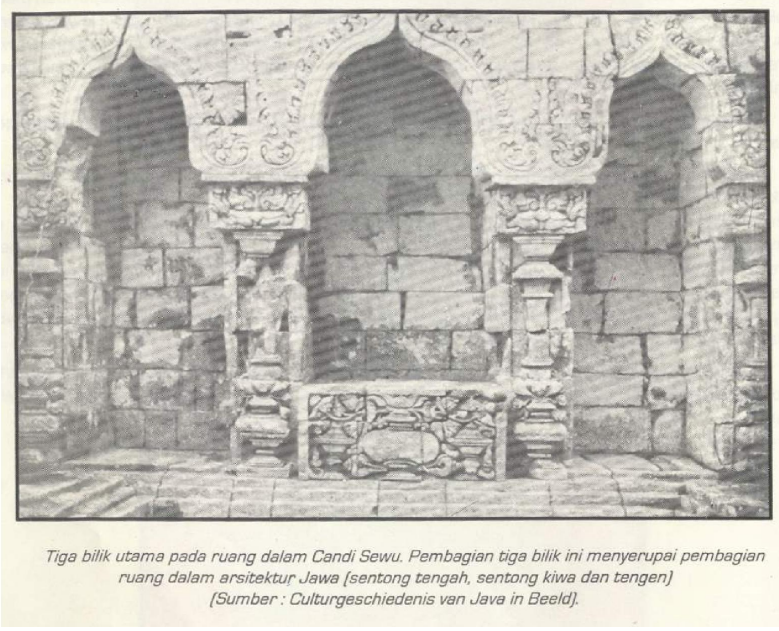

Gambar 1 Tiga Bilik Utama Ruang Dalam Candi Sewu

(Sumber : repro buku "Pasren dalam Kehidupan Masyarakat Tradisionial Jawa”)

Pasren biasa ditempatkan di senthong tengah bagian dalem rumah tradisional Jawa. Senthong terletak di bagian belakang bagian pokok yang dipisahkan dengan sekat pada bagian tiang pokok. Sekat pemisah biasanya dibuat dari bahan kayu atau bambu dan disebut patangaring. Sekat yang terbuat dari kayu biasanya berukir, motifnya kadang tergantung dari selera pemilik rumah. Motif yang biasanya dipilih antara lain motif tumbuh-tumbuhan, atau ukiran wayang. Bentuk ukiran biasanya dapat berupa "krawangan" atau timbul. Patangaring ini membatasi seluruh bagian belakang rumah pokok (dalem).

Penempatan pasren didasarkan pranata kehidupan masyarakat Jawa dan disesuaikan dengan bentuk rumah arsitektur Jawa, baik itu yang terdiri dari pendopo dan dalem yang terletak di bangunan joglo maupun dari bentuk rumah tradisional Jawa lainnya, seperti bangunan rumah bentuk limasan, bentuk kampung, bentuk mesjid dan tajug maupun rumah bentuk panggang-pe. Namun mengingat kondisi sosial ekonomi masyarakat itu berbeda, bangunan pasren tetap dimiliki oleh sekelompok masyarakat atau orang yang menganut falsafah hidup Jawa, walau seseorang tersebut tidak memiliki rumah seperti apa yang diharapkan.

Letak pasren di senthong tengah mempunyai makna sebagai jantung dari kedudukan rumah tangga yang abadi dan letak pasren tidak dapat berubah walaupun bentuk rumah tersebut hanya memiliki rumah pokok saja. Fungsi senthong kiwa biasanya digunakan untuk menyimpan barang-barang atau atribut yang ada kaitannya dengan upacara kesakralan. Misalnya untuk menyimpan pedaringan yang di dalamnya berisi beras dalam jumlah banyak. Pedaringan biasanya terbuat dari tanah liat atau gerabah yang tertutup. Fungsi senthong tengen adalah untuk menyimpan benda-benda atau atribut yang ada hubungannya dengan fungsi pasren, misalnya : untuk menyimpan tikar yang sering dipakai untuk melaksanakan kegiatan upacara, menyimpan kelambu, sarung, bantal, guling, atau berfungsi sebagai tempat tidur. 


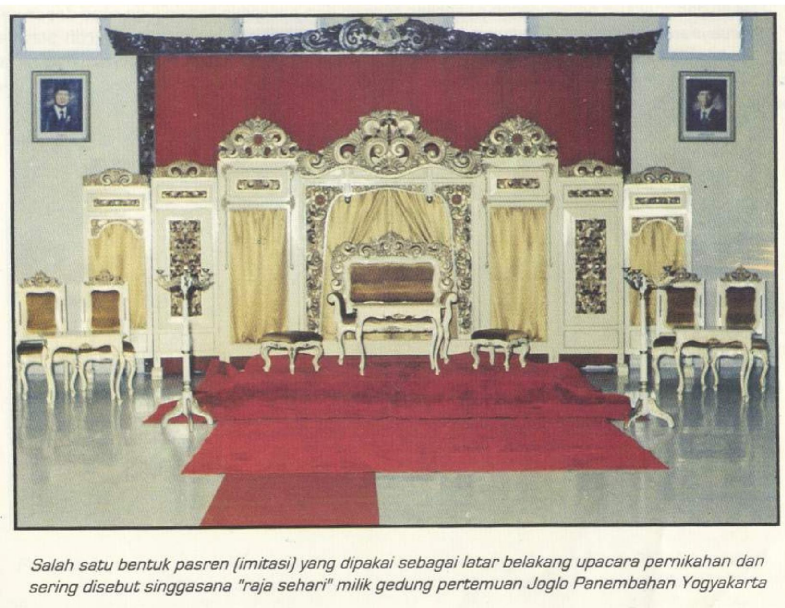

Gambar 2 Pelaminan Pengantin Jawa Bentuk Pasren.

(Sumber : repro buku "Pasren dalam Kehidupan Masyarakat Tradisionial Jawa”)

Menurut falsafah Jawa dalam ruang lingkup Keraton Yogyakarta dan sekitarnya, penempatan pasren disesuaikan dengan letak rumah. Biasanya tatacara yang dianut, rumah harus menghadap ke utara atau selatan. Maksud dan tujuannya tidak lain adalah agar tidak melawan atau membelakangi arah putaran dunia. Utara-selatan dianggap sebagai poros putaran dunia, dan perlambang siklus hidup manusia dari lahir sampai mati. Hal ini dimaksudkan untuk menghindari hal-hal yang tidak diinginkan dari kehidupan manusia dari hari ke hari berikutnya. Selain itu penempatan pasren di tengah, konon juga berasal dari cerita dan kepercayaan masyarakat Yogyakarta tentang keharusan untuk menghormati roh para leluhur yang menghuni atau bersemayam di daerah utara yaitu Gunung Merapi, dan selatan yaitu Ratu Kidul dari pesisir pantai selatan.
Tabel 1 Perbandingan skema candi Prambanan dan rumah bentuk joglo yang sangat terpengaruh struktur budaya Hindu

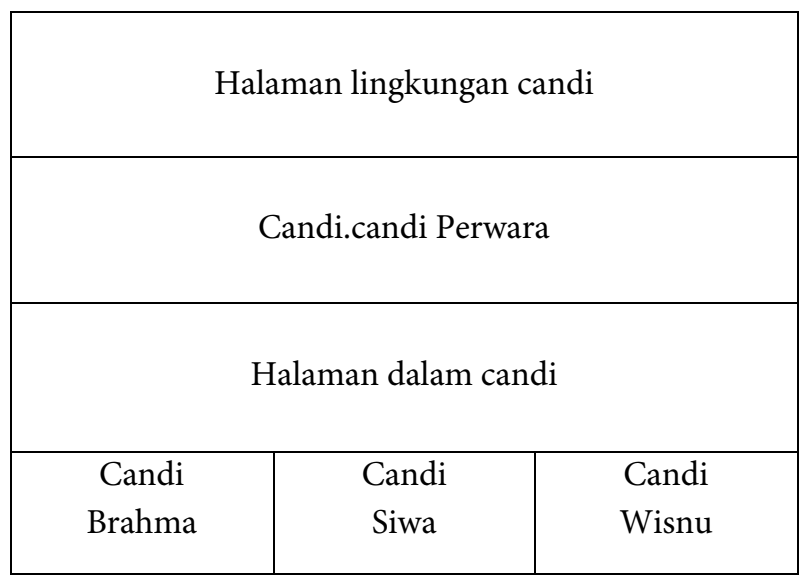

\begin{tabular}{|c|c|c|}
\hline \multicolumn{3}{|c|}{ Pendopo } \\
\hline \multicolumn{3}{|c|}{ Pringgitan } \\
\hline \multicolumn{3}{|c|}{ Dalem } \\
\hline $\begin{array}{c}\text { Senthong } \\
\text { Kiwo }\end{array}$ & Pasren & $\begin{array}{c}\text { Senthong } \\
\text { Tengen }\end{array}$ \\
\hline
\end{tabular}

\section{PASREN DAN FUNGSINYA DALAM KEHIDUPAN MASYARAKAT}

Fungsi pasren yang terpenting adalah sebagai tempat upacara adat di Jawa, seperti:

1. Untuk upacara penghormatan Dewi Sri Dalam masyarakat Jawa, Dewi Sri sebagai pujaan orang-orang yang bermata pencaharian bertani menunjukkan adanya hubungan secara pribadi. Untuk mengetahui bagaimana dan sampai di mana penghormatan terhadap Dewi Sri, perlu diketahui terlebih dahulu di mana kedudukan Dewi Sri dalam ajaran agama Hindu dan kedudukan Dewi Sri menurut pandangan suku Jawa. 
Dalam ajaran agama Hindu, dikenal adanya Dewa Trimurti (Brahma, Siwa, dan Wisnu) dan Dewa Lokapala. Trimurti merupakan puncak dewa dari sekian banyak dewa yang dikenal dalam agama Hindu. Sedangkan Dewa-dewa Lokapala antara lain: Indra, yaitu Dewa Perang sebagai penghulu para Dewa Lokapala, Agni sebagai Dewa Api, Yama yaitu Dewa Maut, Surya sebagai Dewi Matahari, Kuwera sebagai Dewa Kekayaan, dan Soma sebagai Dewa Bulan yang merupakan dewa terakhir dan menempati wilayah sebelah timur.

Dewi Sri dipercaya bukan sebagai penjelmaan dari Dewa Kekayaan (Kuwera). Akan tetapi Dewi adalah penjelmaan Wisnu dan dipuja sebagai Dewi Kebahagiaan. Kedudukan Dewi Sri yang dipercaya sebagai perwujudan Dewa Wisnu menandaskan bahwa kedudukan Dewi Sri sangatlah tinggi karena termasuk dalam jajaran dewa-dewi Trimurti. Dilihat dari tugas dan kewajibannya, Dewi Sri memiliki kewenangan lebih luas daripada Kuwera. Tugas yang diemban Kuwera merupakan sebagian tugas dari Dewi Sri.

Dari pengertian tersebut di atas, maka tidaklah terlalu mengherankan bila orang Jawa sangat menghormati Dewi Sri karena Dewi Sri adalah tempat mereka menaruh harapan dan menggantungkan diri atas kemurahan Dewi Sri sebagai Dewi Kebahagiaan.

2. Sebagai tempat upacara dalam prosesi pengantin Jawa.

Dalam prosesi pengantin Jawa dikenal adanya upacara Beduduk, Asok Tukon, Midodareni, Tampa Kaya, dan Panggih
Pengantin. Semua prosesi ini biasa dilakukan di depan pasren.

a. Upacara Beduduk, dimaksudkan sebagai harapan agar pengantin kelak mempunyai anak yang sehat seperti anak-anak ayam yang pulang kandang.

b. Asok Tukon, pemberian peningset dari pihak calon pengantin pria yang berupa barang-barang seperangkat pakaian wanita terhadap pihak calon pengantin wanita.

c. Midodareni, berarti malam yang mengandung pengertian dan pengetahuan, sebab pada malam midodareni tersebut calon pengantin berdua diperkenalkan kepada sanak saudara. Dalam kepercayaan Jawa, pasren dipercaya dibuat untuk yang pertama kalinya oleh para dewa-dewi, oleh karena itu diharapkan pada malam midodareni, dewa-dewi turun ke dunia untuk memberkahi mempelai berdua.

d. Tampa Kaya, dilaksanakan sebelum upacara panggih temanten, yaitu calon pengantin pria menyerahkan kekayaan berupa harta kekayaan yang terdiri dari : satuan uang, seperangkat perhiasan wanita, sebagian bahan makanan dan perlengkapan kecantikan yang diterima oleh pihak calon pengantin wanita yang selanjutnya diteruskan dengan upacara sungkeman.

e. Panggih pengantin, biasanya dilaksanakan setelah akad nikah, dimulai dengan balang<balangan suruh (saling melempar sirih), menginjak telur, menuang biji-bijian 
untuk kemudian bersanding bersama di pelaminan.

Semua prosesi ini mengandung makna memohon pada para dewa agar berkenan melimpahkan berkahnya, mengharapkan kelanggengan dalam berumah tangga, dan Dewi Sri berkenan memberikan kebahagiaan. Karena maksud-maksud tersebut itu pulalah maka orang tua dan alim ulama memberikan petuah-petuahnya di depan pasren pada malam midodareni tersebut.

\section{TEKNOLOGI DAN MODERNITAS, SIMBOL BARU KEMAJUAN DAN KEMAKMURAN}

Seiring berjalannya waktu, pasren tak banyak dikenal lagi terutama oleh generasi muda bahkan oleh mereka yang lahir dan menetap di Jawa Tengah dan DIY. Pasren hanya dikenal oleh sebagian masyarakat utamanya yang berprofesi sebagi petani dan mengolah tanah dengan cara tradisional. Dalam hal ini para ahli menyatakan bahwa pengaruh luar berkontribusi besar dalam menggeser keberadaan pasren dalam rumah-rumah tradisional Jawa (Dakung (ed.), 1981: 210).

Pengaruh luar yang mempengaruhi arsitektur tradisional ini terutama banyak terdapat pada bahan-bahan bangunan. Dalam arsitektur tradisional pada umumnya komponen-komponennya banyak dibuat dari kayu dan bambu. Karena adanya pengaruh dari luar maka bahan-bahan tersebut diganti dengan batu atau besi. Adapun faktor penyebabnya adalah faktor ekonomi yang selalu menekankan pada alasan efisiensi dan permanen, sehingga dalam pemeliharaan selanjutnya tidak akan banyak lagi mengeluarkan biaya. Oleh karena itu beberapa bagian rumah seperti misalnya dinding bambu (gedheg) diganti dengan papan, tembok, atau kombinasi papan dan tembok.

Bila kita lihat secara keseluruhan misalnya pada bentuk rumah joglo yang banyak dibangun sekarang ini, sudah tidak lengkap dibanding dengan bangunan joglo yang dibuat dulu. Tetapi prinsip bangunan bentuk joglo masih banyak dipakai hingga sekarang. Pada dasarnya bangunan joglo terdiri dari pendapa, pringgitan, dan senthong serta dalem. Di sekelilingnya yang disebut gandhok saat ini sudah jarang dibuat. Hal ini lebih karena alasan keterbatasn lahan (karena semakin menyempit dibagi-bagi kepada ahli waris pemilik tanah/ rumah), serta alasan ekonomis yaitu biaya pembuatan rumah joglo lengkap memerlukan biaya yang sangat mahal. Sebagai gantinya, masyarakat Jawa saat ini lebih menyukai bangunan yang lebih sederhana, yaitu dengan arsitektur barat yang bentuknya blok atau persegi bagaikan kotak.

Pengaruh luar yang lain adalah masuknya budaya Islam yang cukup berpengaruh sehingga pasren tidak lagi ditemui dalam rumah tradisional. Walaupun sebagian masyarakat Jawa adalah masyarakat yang sinkretis, tetapi banyak pula yang tidak membuat pasren di dalam rumahnya. Pemujaan terhadap Dewi Sri sudah dianggap tidak relevan lagi.

Dalam tulisan hasil penelitian lapangannya di tahun 70-an mengenai mendandani desa dengan tugu dan pagar beton di masa Orde Baru, Teruo Sekimoto menyoroti mengenai betonisasi sebagi simbol kemajuan pembangunan dan modernitas baru di pedesaan di Jawa. Saat itu hampir seluruh desa dipenuhi dengan pagar-pagar beton, gapura dan tugu-tugu beton yang mencolok serta aneh 
dalam pandangan Sekimoto. Tugu, pagar dan gapura ini dibuat oleh masyarakat di sebuah desa di Jawa dalam rangka peringatan Hari Kemerdekaan Republik Indonesia 17 Agustus 1945.

Dulu, pagar-pagar bambu dengan rapi dibangun oleh tiap-tiap keluarga dengan gaya beragam yang tampak serasi dengan tanaman di tiap-tiap halaman. Seperti persawahan desa yang dipelihara dengan rajin, saluran-saluran irigasi, dan kebunkebun di rumah, pagar-pagar bambu ini merepresentasikan sebuah tradisi panjang kehidupan agraris di Jawa. Pagar dan gerbang beton yang baru, di lain pihak, tampaknya meninggalkan tradisi tersebut dan mencerminkan keseragaman pemerintahan negara (Sekimoto, 1997:486).

Lebih lanjut Sekimoto juga menuliskan:

Konsep maju ini merupakan konsep yang paling akrab di Indonesia jauh sebelum era Orde Baru. Konsep ini terus mempertahankan kekuatannya yang tidak dipertanyakan lagi pada tahun 1970-an dan 1980-an dalam pengertian bahwa apa pun yang berarti maju maka itu berarti baik dan disukai. Dalam percakapan sehari-hari penduduk desa, kata ini digunakan terutama untuk merujuk objekobjek nyata dan teknik-teknik, kadangkadang digunakan untuk menunjuk ciriciri abstrak manusia, kelompok, atau organisasi. Seseorang dikatakan maju jika makanan hariannya terdiri dari protein seperti tahu, tempe, atau telur. Sebuah desa dianggap maju jika lebih banyak rumah yang terbuat dari bata daripada dinding anyaman bambu. Diantara para penduduk desa ini konsep maju juga mengingatkan pada pusat-pusat perkotaan besar, terutama Jakarta. Pendek kata, maju berarti modernitas: gaya hidup perkotaan modern, kekayaan materi, latar belakang pendidikan yang baik, dan pekerjaan kantoran (Sekimoto, 1997 : 487).

Berdasar pengamatan Sekimoto anakanak muda yang dapat berbahasa Indonesia, cukup terpelajar dan dengan mudah memiliki sarana akses lebih baik ke kota yang lebih besar, mendapat kedudukan khusus di dalam masyarakat. Dalam kegiatan-kegiatan sosial seperti kerja bakti desa misalnya, mereka merasa lebih berhak untuk mendominir secara implisit pada setiap perencanaan dasar dan verbalisasi ideologis dari kerja bakti, dibanding warga lain yang tidak terpelajar. dan berprofesi sebagai petani. Maka bagi anak-anak muda yang terpelajar ini, walaupun orang tua mereka memiliki lahan yang cukup luas untuk digarap, mereka sama sekali tidak tertarik untuk menjadi petani. Bagi mereka, pekerjaan sebagai buruh tani mewakili ketertinggalan dan kebodohan orang-orang yang tidak berpendidikan. Oleh karena itu, akhirnya mereka sangat sering bermalas-malasan di sudut-sudut desa (Sekimoto, 1997: 463).

Menjadi petani dianggap sebagai profesi yang tidak bergengsi. Menjadi kaum terpelajar, kaum priyayi kantoran lebih dianggap bermartabat, maju dan terhormat. Itulah mengapa pada akhirnya pola orientasi ini mengubah pola perilaku. Yang semula tani oriented berubah ke intelek oriented. Perubahan orientasi hidup tentulah akhirnya akan mempengaruhi cara hidup dan juga bentuk rumah tempat tinggal sebagai bagian dari sarana hidup.

Perubahan orientasi ini rupanya tidak diimbangi dengan pola pikir yang signifikan. Walaupun pola orientasi yang diiinginkan adalah menjadi priyayi, banyak orang Jawa 
yang tidak mengimbanginya dengan etos yang tepat. Etos priyayi yang diterapkan seringkali masih berkiblat pada asumsi priyayi di masa kolonial.

Jauh mundur ke belakang, di tahun 50-an bisa dikatakan menjadi awal apa yang disebut dengan kampanye modernitas oleh pemerintah Hindia Belanda. Dalam tulisannya mengenai "Let's Become Radio Mechanics": Technology and National Identity in Late $<$ Colonial Netherlands East Indies oleh Rudolf Mrazek disebutkan bahwa radio adalah simbol baru modernitas dan kemakmuran. Hal ini seiring masuknya listrik. Dalam tulisannya, Mrazek menyebutkan bahwa radio merupakan suatu cara mengimitasi/mengimajinasikan kolonialisme sebagi ritus modernisasi oleh pemerintah kolonial Belanda. Oleh karenanya, menjadi mekanik radio merupakan suatu profesi bergengsi di Hindia Belanda saat itu (Mrazek, 1997).

Tahun 70-an, yang sering dianggap sebagai masa keemasan Orde Baru, giliran pesawat televisi menjadi barang mewah baru yang mulai gampang dimiliki oleh tiap keluarga. Televisi menjadi simbol modernitas, kemakmuran dan sekaligus pada faktanya menjadi sumber kebahagiaan (yang walaupun semu) tapi sangat didambakan kehadirannya di tengah keluarga.

Konsep keluarga pun, senyatanya tidak lepas dari rekonstruksi yang dilakukan pemerintah. Dulu di masa Orde Baru, kita mengenal Keluarga Berencana dengan jargonnya yang berupa Norma Keluarga Kecil Bahagia dan Sejahtera. Konsep Keluarga Berencana merupakan program yang dijalankankan pemerintah untuk pengendalian jumlah penduduk. Dalam perkembangannya kemudian, Keluarga Berencana dikembangkan antara lain untuk menggeser keyakinan masyarakat (terutama Jawa), "banyak anak banyak rejeki" dengan "dua anak cukup, lakilaki atau perempuan sama saja". Di masa jayanya, program ini berhasil dengan sukses, hingga pemerintah Indonesia mendapat banyak penghargaan internasional. Saat ini pun, program KB mulai dilirik kembali seiring angka pertambahan penduduk yang kembali melonjak dan kasus gizi buruk balita mulai merajalela.

Antara "banyak anak banyak rejeki" dengan "dua anak cukup" adalah dua pernyataan yang mengandung oposisi. Akan tetapi, keyakinan yang ingin ditampilkan oleh keduanya adalah sama, yaitu bahwa anak adalah sumber kemakmuran dan kebahagiaan, namun dicapai dengan cara yang berlainan. Yang satu meyakini datangnya kebahagiaan karena hadirnya banyak anak, sedangkan program KB berusaha meyakinkan bahwa tidak saja kebahagiaan tetapi juga kesejahteraan akan lebih terjamin dengan sedikit anak (dua anak).

Hubungan antara konsep pasren dengan anak amatlah dekat. Pasren digunakan sebagai tempat persandingan pelaminan dan berperan penting dalam ritual penganten. Hal yang paling diharapkan dalam suatu perkawinan adalah anak. Dengan demikian pasren sekaligus menjadi simbol pengharapan akan datangnya kebahagiaan berupa dikaruniainya rumah tangga yang langgeng dan dikaruniai anak bagi sepasang penganten.

Berbagai inseminasi konsep modernitas dan kemajuan tadi menjadikan keberadaan tradisionalitas menjadi sesuatu yang mulai ditinggalkan, termasuk keberadaan pasren di rumah-rumah orang Jawa. Tetapi senyatanya konsep pemujaan, pengharapan akan kebahagiaan dan kemakmuran tidak pernah 
surut dari tiap batin seseorang. Hanya saja sarana-sarananya berganti, bertransformasi dalam wujud-wujud yang lain.

\section{TELEVISI: $\quad$ SEBUAH $\quad$ BENTUK TRANSFORMASI}

Pengamatan di beberapa dekade lalu ketika era digital, gawai, dan internet belum semasif sekarang, terlihat bahwa sesungguhnya orang seringkali tidak menyadari bahwa dia tanpa sadar telah mendudukkan televisi sebagaimana masyarakat tradisional meletakkan pasren dalam rumahnya (tetapi tentu tidak diartikan bahwa masyarakat saat tersebut memuja televisi sebagaimana pemujaan terhadap Dewi Sri). Pernahkah anda mengamati bagaimana kecenderungan seseorang (terutama di daerah Jawa Tengah atau DIY) untuk meletakan teve yang dimilikinya di dalam rumah kala itu? Biasanya teve akan diletakkan di ruang tengah, ditata atau diletakkan ke dalam bufet tinggi berukir dengan rongga khusus di tengah. Bufet ini banyak macam ragam desainnya dan sangat populer di era 80 -an. Salah satu model yang amat tren berupa bufet tinggi dengan ukiranukiran motif sulur dari Jepara. Kayunya berplitur coklat muda bergradasi hingga desain dengan warna coklat tua. Rongga di tengah disediakan khusus untuk wadah teve, cukup untuk teve ukuran 21 inch. Ukirannya mengingatkan kita pada ukiran pada krobongan, dan posisi serba tengah-nya juga mengingatkan kita pada pasren yang tidak boleh digeser-geser. Model lain bentuknya seperti lemari kaca, dengan tiga deret bagian. Bagian bawah bertutup dua pintu lemari. Bagian atasnya terbagi menjadi tiga bagian. Bagian kiri dan kanan bertutupkan kaca, simetris mengapit bagian tengah yang di tengahnya lagi, berongga khusus untuk wadah teve.

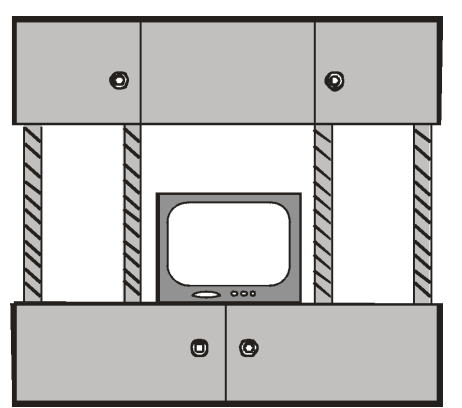

Gambar 3 Ilustrasi contoh buffet kayu berisi televisi

Televisi adalah kotak ajaib yang menjadi salah satu 'cinderamata dari abad 20' yang kehadirannya cukup mampu mempengaruhi dunia. Sejak diciptakan kurang dari seratus tahun yang lalu, televisi telah mengalami perkembangan pesat baik dari segi tampilan maupun teknologinya. Gambar-gambar yang mampu bergerak, bersuara, dan berwarna, menjadi daya tarik yang sangat dahsyat dari televisi. Tak heran, televisi menjadi salah satu barang rumah tangga yang paling dicari dan menontonnya pun menjadi salah satu kegiatan konsumtif yang paling menyita waktu bagi ibuibu rumah tangga dan anak-anak (Budiman, 2003). Dengan menonton televisi, semua orang menjadi mampu belajar banyak hal, baik dalam kategori yang positif maupun negatif. Anakanak balita belajar berhitung dasar satu sampai sepuluh bersama kereta Thomas atau karakter bus imut Tayo tetapi juga turut 'belajar' mengekspresikan marah yang berlebihan dengan memelototkan mata dengan dada terengah-engah seperti yang diajarkan tayangan sinetron. Tak pelak televisi merupakan media simulacrum yang paling disorot.

Banyak penelitian telah mengungkapkan bahwa tayangan televisi turut menciptakan tren 
di belahan dunia. Bagaimana kategori perempuan ideal dikonstruksikan sebagai perempuan dengan kulit putih, rambut lurus, tubuh langsing semampai dan selalu berpenampilan segar dan rapi. Bagaimana keluarga yang bahagia naik mobil yang mewah dengan suasana sejuk : bapak, ibu, dan dua orang anak yang sehat dan ceria, dan seterusnya. Semua ini menempatkan televisi sebagai benda yang sanggup selalu memberi penghiburan yang murah dan tanpa lelah, dan juga menempatkan televisi sebagai simbol baru bagi kemakmuran (di era kejayaan televisi, keluarga yang tidak memilikinya acap kali dianggap sebagai keluarga yang kurang mampu secara ekonomi), dan simbol pengharapan (dengan menonton televisi, orang akan sejenak melupakan beban hidup dan kesusahannya, mengharap rejeki nomplok, atau memantau berbagai berita).

Dengan berbagai aspek yang dimiliki televisi ini maka tak heran bila hampir semua keluarga pada umumnya menempatkan televisi sebagai benda yang dikonsumsi bersama seluruh keluarga dan ditempatkan pada ruangan yang paling sering diakses oleh seisi rumah. Ruangan tersebut adalah ruang tengah, dimana televisi di letakkan pada posisi yang tidak mudah digeser-geser, posisi yang cukup aman dari maling yang mungkin masuk ke dalam rumah, dan posisi istimewa lain yaitu selalu dikelilingi oleh seluruh anggota keluarga pada jam-jam tertentu ketika mereka menonton bersama.

Memang terkesan sangat semena-mena mensejajarkan antara pasren dengan televisi. Tetapi dalam hal ini saya sama sekali tidak bermaksud merendahkan makna pasren bagi mereka yang menganut falsafah Jawa. Saya hanya mencoba mencari struktur tertentu yang diam, yang meneng dalam fenomena yang saya amati ini. Struktur yang diam, tak berubah sama sekali inilah deep structure dari berbagai simbol dan proses simbolisasi fenomena budaya yang dipelajari. Deep structure merupakan model yang dibuat oleh si ahli antropologi untuk memahami kebudayaan yang dipelajarinya (Ahimsa-Putra, 2001: 65).

\section{KONSEP KELUARGA BERENCANA: SEBUAH KASUS PADA SEBUAH TUGU KB}

Di masa orde baru, kita banyak mendapati jargon-jargon yang disosialisasikan pemerintah ke seantero nusantara. Ada modernisasi desa dengan proyek listrikisasi dan mekanisasi pertanian, dan juga Keluarga Berencana. Bila kita amati, dalam program $\mathrm{KB}$, simbolisasi terhadap pengharapan dan kemakmuran seringkali coba ditanamkan oleh pemerintah Orde Baru yang lalu melalui program ini. Dari semboyan "banyak anak banyak rejeki" yang banyak dianut orang Jawa di masa itu, menjadi semboyan "dua anak cukup". Dalam semboyan orang Jawa "banyak anak banyak rejeki", anak adalah rejeki. Anak adalah sumber kebahagiaan. Orang Jawa membutuhkan banyak anak untuk mengolah tanah pertaniannya yang luas. Tetapi dalam perkembangannya kemudian, lahan yang luas berangsur terbagi menjadi lahan yang makin menyempit karena dalam adat orang Jawa, semua anak mendapat bagian warisan tanah dari orangtuanya. Anak yang banyak dan lahan yang makin terbagi, menjadikan lahan makin menyempit dan tingkat kemakmuran pun makin menurun. Akibatnya, muncul istilah "shared poverty" di tanah Jawa, kemiskinan yang terbagi. Jumlah penduduk yang melonjak yang tidak diiringi dengan perluasan lahan, dikhawatirkan menyebabkan peledakan jumlah 
penduduk yang tidak terkendali. Untuk mengatasinya maka pemerintah menggalakkan program KB. Program KB berusaha mengikis mitos "banyak anak banyak rejeki" dengan semboyan "dua anak cukup". Dengan semboyan yang baru ini, pemerintah ingin menyadarkan masyarakat bahwa banyak rejeki justru tidak akan dicapai dengan banyak anak, tetapi cukup dengan dua anak saja. Asumsinya semakin sedikit jumlah anak maka semakin mudah mengatur kesejahteraan mereka, sehingga kesejahteraan lebih mudah tercapai.

Sebagaimana telah disinggung di atas, program KB adalah salah satu program tersukses yang berhasil dilaksanakan pemerintah Orde Baru. Di masa itu, orang sudah sampai pada tingkat rasa malu yang sangat bila kedapatan mempunyai anak banyak, lebih dari dua. Seseorang dengan anak banyak, dengan mudah mendapat stigma tidak modern, tidak taat pada aturan pemerintah, dan sebagainya. Seseorang lebih mudah berpeluang dianggap menjadi warga terhormat dengan memiliki dua anak saja. Apalagi waktu itu, pemerintah juga sangat giat memberi berbagai macam penghargaan-penghargaan kepada para kader KB dan PKK (Pembinaan Kesejahteraan Keluarga) di daerah yang dianggap berhasil melaksanakan programprogram KB. Keluarga Berencana tak pelak menjadi isu kebijakan pemerintah Orde Baru yang terpenting di samping transmigrasi dan modernisasi desa.

Dalam kasus ini, didapati ada suatu tugu KB yang sangat menarik. Tugu itu dapat dilihat di sebuah desa di Bantul. Tepatnya Desa Sabdodadi, Kecamatan Bantul Kota. Di tengah banyaknya tugu, gapura, dan pagar beton yang rubuh karena gempa 2006 silam, tugu KB ini masih tegak berdiri. Yang unik, bentuk tugu ini seperti pasren. Berdasar informasi pembuatnya, yaitu mantan kepala desa Sabdodadi, beliau tidak menyadari struktur yang dibuatnya tersebut. Menurut si pembuat, bentuk itu dibikin karena biar kelihatan bagus saja.

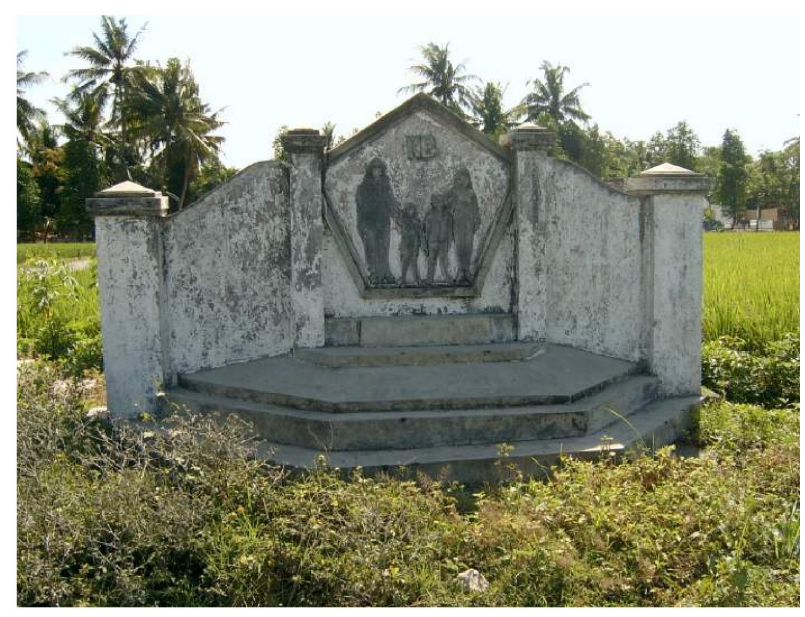

Gambar 4 Tugu KB di salah satu sudut Desa Sabdodadi, Kecamatan Bantul, Kabupaten Bantul

Fenomena ini dalam pandangan saya merupakan salah satu apa yang disebut LeviStrauss sebagai dua cara kerja ilmu pengetahuan. Ilmu pengetahuan menurut LeviStrauss memiliki dua cara kerja: entah secara reduksionistis atau secara strukturalis. Ilmu pengetahuan bekerja secara reduksionistis, apabila ditentukan bahwa fenomena yang sangat kompleks dari suatu tingkat tertentu dapat direduksikan ke dalam sejumlah fenomena yang sederhana dari suatu tingkat yang lain (Strauss, 1997: 51). Pendapat Strauss ini menyatakan bahwa cara berpikir manusia sangat terstruktur dan seolah ada kekuatan di luar manusia yang mengaturnya. Dalam kasus tugu KB ini saya menduga bahwa ketika membuat tugu dan ternyata bentuknya seperti pasren, si empunya tidak sadar konsep yang dikategorikan bagus atau jelek menurut 
paradigma ilmu tertentu. Dia membuat berdasarkan selera atau feeling-nya saja. Dengan demikian sebetulnya si pembuat telah melakukan suatu tindakan yang tidak terstruktur menurut kategori akademis, tetapi justru telah melakukan tindakan terstruktur dalam pandangan teori Levi-Strauss. Buktinya, si pembuat membuat suatu bentuk yang dalam pikirannya dianggap bagus. Bagus atau tidaknya sesuatu biasanya tentu akan dikaitkan dengan apa yang pernah dilihatnya. Ketika secara common sense orang biasa menerima konsep kemakmuran dan pernikahan yang menghasilkan anak biasa dilakukan di depan pasren, maka ketika menggambarkan anak, Keluarga Berencana, dan sekaligus sebagai sosialisasi proyek pemerintah, tanpa disadari bentuk seperti itulah yang dibuat.

Selain itu, bila kita perhatikan, komposisi penggambaran Ayah - ibu-dua anak dalam lambang KB selalu digambarkan dengan posisi ayah-ibu mengapit dua anaknya. Dalam pengamatan saya, ini mengandung makna bahwa anak, dengan ditempatkan di tengah berarti menjadi centre, menjadi pusat dari keluarga. Tentu visualisasi ini bisa dimaknai bahwa KB adalah program yang berorientasi pada anak. Bandingkan dengan foto-foto keluarga dengan banyak anak, kita cenderung mendapati posisi ayah-ibu berada di tengah dengan anak-anak berkerumun di sekelilingnya. Demikian pula foto-foto lama para bupati Jawa beserta pegawai-pegawainya, kita akan mendapati pola yang sama, yaitu dengan posisi sang bupati berada di tengah.

\section{PENUTUP}

Konsep "tengah" bukanlah konsep yang baru dalam masyarakat Jawa. Penelitian yang mendalam oleh para ahli antropologi mengenai struktur dalam (deep structure) pada masyarakat Jawa menemukan bahwa "tengah" merupakan pusat dari segalanya. Konsep "sedulur papat lima pancer" misalnya, senada dengan konsep hari pasaran Jawa, organisasi sosial "moncopat", dan juga tata letak keraton Yogyakarta.

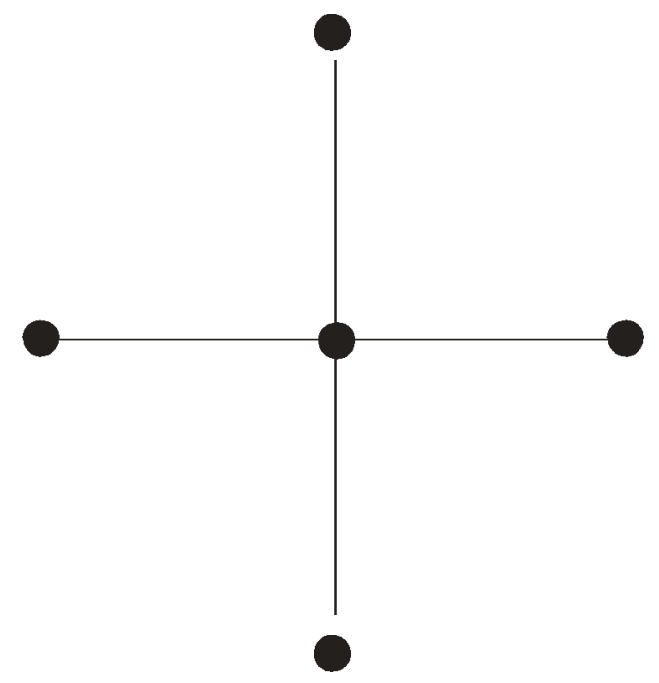

Gambar 5 Struktur dalam yang muncul dari konsep Jawa "sedulur papat lima pancer", hari pasaran Jawa, organisasi sosial "moncopat", dan juga tata letak keraton Yogyakarta.

Selain itu, "tengah" sebagai pusat muncul pula dalam pergelaran wayang, yaitu adanya goro-goro di tengah pertunjukan. Adegan gorogoro adalah lawak diantara para punakawan, yang biasanya muncul di tengah pertunjukan. Dengan demikian kurang lebih muncul sekitar tengah malam dalam pertunjukan wayang yang semalam suntuk. Dilihat dari alur cerita, maka munculnya goro-goro selalu bertepatan dengan puncak alur cerita, saat masalah yang dibangun oleh Ki Dalang telah mencapai titik puncaknya dan dengan demikian harus diberi pemecahan. Ketegangan lakon yang tercapai, dicairkan dan dilunakkan dengan adegan lawak goro-goro ini. Setelah adegan goro-goro, maka semua adegan 
tegang untuk menyelesaikan masalah lakon dapat dikendurkan dengan lawakan yang dicetuskan lewat para punakawan. Sampai kepada pemecahan masalah dalam lakon di pagi hari alur cerita selalu berada antara ketegangan dan pengenduran karena lawakan. Bila diamati, maka kita dapat melihat bahwa adegan lawak tidak pernah absen dalam pertunjukan rakyat tradisional. Dari sini dapat ditarik dugaan sementara bahwa pola pemecahan masalah dalam teater Jawa tidak dicapai dengan ketegangan secara total, tetapi ketegangan yang dijalin dengan pengenduran. Kontras kekasaran dengan kehalusan disertai dengan pengenduran merupakan estetik dasar dalam pandangan Jawa. tipe kasar dan halus serta tipe gembira (ringan) sebagai tipe penengah bukan hanya terdapat pada pertunjukan rakyat, pergelaran tari dan pewayangan sajaZ keris, batik, suara burung perkutut, tipe kuda, bahkan tipe wanita dikelompokkan menurut kelompok ini (Kartodirdjo, 1987: 119).

Kelompok penengah, demikian istilahnya, tidak lepas dari pandangan kosmos orang Jawa mengenai bagian pangiwa dan bagian panengen. Dalam bagian pangiwa terletak segala unsur jahat, kasar, dan nafsu untuk menghancurkan. Bagian panengen mengandung unsur yang baik, halus, tenang, dan nafsu untuk membangun. Meskipun disadari bahwa malapetaka berasal dari bagian kosmos pangiwa namun orang tidak akan mengikis habis bagian ini, bahkan juga sangat toleran terhadap bagian kejahatan itu, karena dianggap sebagai bagian yang mutlak harus ada dalam alam kosmos. Karena bagian pangiwa yang berisi anasir jahat mutlak harus ada di dunia kosmos maka sikap masyarakat Jawa dalam menghadapi kejahatan tidak pernah fanatik (Kartodirdjo, 1987: 121). Demikianlah, dari uraian di atas kita dapat menarik gambaran mengenai kedudukan "tengah" menurut kosmologi orang Jawa.

Jika kemudian struktur ini tidak hanya berhenti pada hal-hal yang bernilai tradisional saja, itulah yang menarik. Rupanya, alam berpikir Jawa ini memang demikian kuatnya sehingga tanpa sadar orang-orang Jawa masih menerapkannya bahkan dalam bentuk kehidupannya yang telah modern seperti bagaimana memperlakukan dan menempatkan televisi di dalam rumah, dan bagaimana mendudukkan konsep Keluarga Berencana dalam sebuah tugu. Dari sinilah, maka kedudukan teori Strukturalisme Levi-Strauss semakin mendapat tempat.

Bila kita gambarkan dalam tabel, kita dapat merunutnya sebagai berikut :

\begin{tabular}{|c|c|c|c|c|c|}
\hline ERA & NO. & $\begin{array}{l}\text { NAMA } \\
\text { BENDA/TEMPAT }\end{array}$ & LETAK & DIAPIT & MAKNA \\
\hline \multirow[t]{2}{*}{ TRADISIONAL } & \multirow[t]{2}{*}{1} & \multirow[t]{2}{*}{ PASREN } & \multirow[t]{2}{*}{ SENTHONG TENGAH } & SENTHONG KIWO & \multirow{2}{*}{\begin{tabular}{l}
\multicolumn{2}{l}{ TEMPAT PEMUJAAN } \\
TERHADAP DEWI \\
SRI \\
KEBAHAGIAAN)
\end{tabular}} \\
\hline & & & & $\begin{array}{l}\text { SENTHONG } \\
\text { TENGEN }\end{array}$ & \\
\hline \multirow[t]{3}{*}{ MODERN } & \multirow[t]{2}{*}{2} & \multirow[t]{2}{*}{ TELEVISI } & \multirow[t]{2}{*}{$\begin{array}{l}\text { RUANG } \\
\text { TENGAH/RUANG } \\
\text { KELUARGA }\end{array}$} & $\begin{array}{l}\text { RUANG } \\
\text { DEPAN/RUANG } \\
\text { TAMU }\end{array}$ & $\begin{array}{ll}\text { TEMPAT } & \\
\text { MENERIMA } & \text { TAMU } \\
\text { DARI LUAR } & \end{array}$ \\
\hline & & & & KAMAR TIDUR & $\begin{array}{l}\text { TEMPAT PRIVACY } \\
\text { TUAN RUMAH }\end{array}$ \\
\hline & 3 & & $\begin{array}{l}\text { LOGO KB DILETAKKAN } \\
\text { DI TENGAH }\end{array}$ & & $\begin{array}{l}\text { DALAM } \\
\text { PANDANGAN }\end{array}$ \\
\hline
\end{tabular}


Kajian Budaya Visual Pasren Dan Transformasi Simbol Kebahagiaan Dan Kemakmuran Pada Masyarakat Modern (Tinjauan Strukturalisme Levi Strauss)

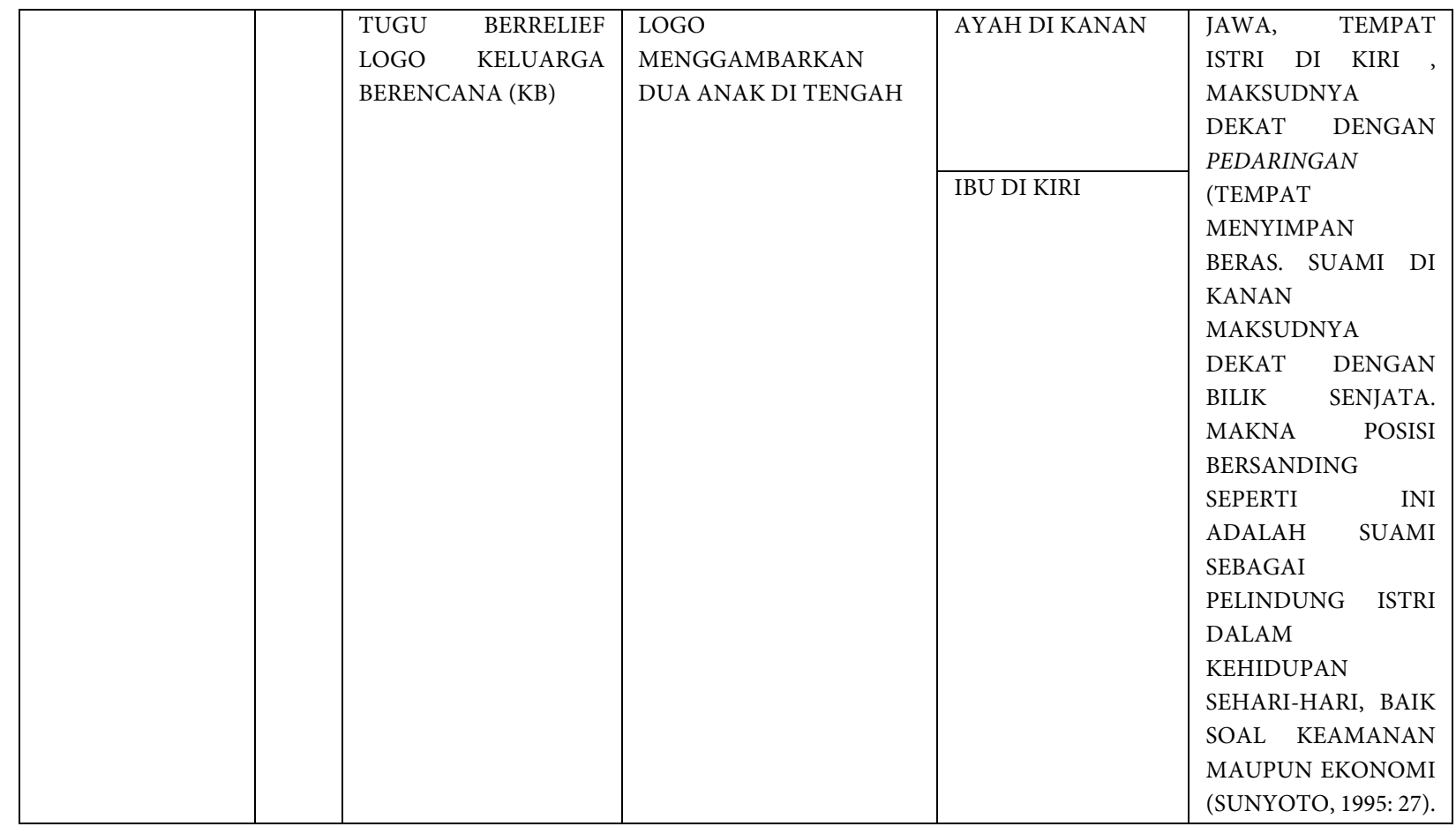

\section{DAFTAR PUSTAKA}

[1] Ahimsa-Putra, H.S. 1997.

"Claude Levi-Strauss: Butir-butir Pemikiran Antropologi" dalam Levi-Strauss. Empu Antropologi Struktural, Oktavio Paz. Yogyakarta: LKiS.

[2] 1999. "Arca Ganesya dan Strukturalisme Levi-Strauss: Sebuah Analisis Awal" dalam Cerlang Budaya. Rahayu S (ed.). Jakarta: PPKB - Lembaga Penelitian UI.

[3] . 2000. "Wacana Seni dalam Antropologi Budaya: Tekstual, Kontekstual dan Post-Modernistis" dalam Ketika Orang Jawa Nyeni. Heddy SAP (ed.). Yogyakarta: Galang Press.

[4] 2001. Strukturalisme LeviStrauss. Mitos dan Karya Sastra. Yogyakarta: Galang Press.

[5] Badcock, Christopher R. 2006 LeviStrauss. Strukturalisme dan Teori Sosiologi. Yogyakarta: Insight Reference.

[6] Budiman, Kris. 2003. Menonton Televisi sebagai Salah Satu Bentuk Konsumsi, Tesis Pasca Sarjana, Jurusan Antropologi,
Fakultas Ilmu Budaya, Universitas Gadjah Mada.

[7] Dakung, Sugiyarto, Drs. (ed.) dkk. 1982 Arsitektur Tradisional Daerah Istimewa Yogyakarta. Yogyakarta: Departemen Pendidikan dan Kebudayaan, Proyek Inventarisasi dan Dokumentasi Kebudayaan Daerah.

[8] Eliade, Mircea. 1961. Images and Symbol: Studies in religious Symbol, Kansas City: Sheed Andrewa and McMeel, Inc.

[9] Floch, Jean Marie. 2000. Visual Identities, London and New York: Continuum.

[10] Geertz, Clifford. 1992 Kebudayaan dan Agama. Yogyakarta: Kanisius.

[11] Kartodirdjo, Sartono., dkk. 1987. Perkembangan Peradaban Priyayi. Yogyakarta: Gadjah Mada University Press.

[12] Mrazek, Rudolf. 2005. “"Let's Us Become Radio Mechanics” : Technology and National Identity in Late-Colonial Netherland East Indies" dalam Comparative Studies in Society and History, Vol. 39, No.1, 3-33.

[13] Sekimoto, Teruo. 2005. "Pakaian Seragam dan Pagar Beton, Mendandani Desa pada 
Masa Orde Baru Tahun1970-an dan 1980an" dalam Outward Appearances, Trend, Identitas, Kepentingan. Henk Schulte Nordholt (ed.). Yogyakarta: LkiS.

[14] Strauss, Levi. 1997. Mitos, Dukun, dan Sihir, Yogyakarta: Kanisius.

[15] Sunyoto, Drs.,dkk. 1995. Pasren dalam Kehidupan Masyarakat Tradisional Jawa. Yogyakarta: Bagian Proyek Pembinaan Permuseuman DIY, Direktorat Jenderal kebudayaan Depdikbud. 